\title{
Individual Educational Paths of Students' Cognitive Activity Development
}

\author{
Vladimir V. Yepaneshnikov ${ }^{\mathrm{a}}$, Vladimir I. Kurdyumov ${ }^{\mathrm{b}}$, Larisa E. \\ Zotovac, Marina U. Kraeva ${ }^{c}$, Natalya I. Besedkina ${ }^{d}$ and Olesya G. \\ Filipenkova ${ }^{e}$
}

aKazan (Volga region) Federal University, RUSSiA; bUlyanovsk State Agricultural Academy named after P. A. Stolypin, RUSSIA; 'Moscow State Regional University, RUSSIA; ${ }^{\text {dFinancial }}$ University under the Government of the Russian Federation, RUSSIA; ePlekhanov Russian University of Economics, RUSSiA

$\begin{array}{ll}\text { ABSTRACT } & \text { ABT }\end{array}$

The relevance of the study is reasoned by the transition to the knowledge economy and the need for the development of students' cognitive activity. The purpose of the article is to identify the types of students' cognitive activity and functions of individual paths of their development. The guiding principle of investigation is the principle of pedagogical creativity, providing a communicative and creative direction of teachers, development of the ability to find new approaches to solving problems. The study involves 200 teachers, 350 students who participated in the identification of criteria for the effectiveness of individual educational paths. The main results of the study are to identify types of cognitive activity (starting, situational, performing, creative), the functions of individual paths of their development (target, content, competence based). The significance of the results obtained is that the identified types of cognitive activity cause the selection of adequate methods for their learning activities to strengthen students' subject position and to move to the individualization of educational paths. The found functions of individual educational paths contribute to the development of students' creative potential, their personal and professional skills needed in the modern conditions of life and professional activities.

\author{
KEYWORDS \\ Cognitive activity, individual educational paths, \\ pedagogical creativity
}

\author{
ARTICLE HISTORY \\ Received 15 July 2016 \\ Revised 30 October 2016 \\ Accepted 07 November 2016
}

\section{Introduction}

The relevance of the study is reasoned by the transition to the knowledge economy and the need for the development of cognitive activity of students. Knowledge Economy as the main factors determines the knowledge and human capital (Lunev,

\section{CORRESPONDENCE V. V. Yepaneshnikov $\square$ epaneshnikov@yandex.ru}

(C) 2017 V. V. Yepaneshnikov et al.

Open Access terms of the Creative Commons Attribution 4.0 International License apply. The license permits unrestricted use, distribution, and reproduction in any medium, on the condition that users give exact credit to the original author(s) and the source, provide a link to the Creative Commons license, and indicate if they made any changes. (http://creativecommons.org/licenses/by/4.0/) 
Pugachova \& Stukolova, 2014). Along with the term "economy based on knowledge", in recent years also the concept "a society based on knowledge» has spread ("the knowledge-based society») or "knowledge society». The documents of the World Science Forum, organized by UNESCO and the International Council for Science in November 2003 in Budapest, give the following definition: "A society based on knowledge, - an innovative society based on lifelong learning concept throughout life. It unites the community of scientists, researchers, engineers and technicians, research networks, as well as firms involved in the process of research and production of hightech goods and services. It forms a national innovation and production system, which is integrated into international networks on production, distribution, use and protection of knowledge. Means of communication and information technologies available in such a society can provide access to the humanities. Knowledge are used for individuals to enrich opportunities in cultural and material terms, and for the construction of a sustainable society » (Knowledge-based society. Budapest, 2003).

The transition to the knowledge economy actualizes the problem of development of students' informative activity (Akhmetov et al., 2016). It is known that the learning process can be represented as a system of perception, memory, storage, interpretation, reproduction and interpretation of the acquired knowledge. It is obvious that the development of cognitive activity can be carried out simultaneously in all components of the system, but can occur at any one (Osmolovskaya, 2006). There are two approaches to the development of cognitive activity: extensive and intensive (Popkov \& Korzhuev, 2007). Both approaches have the same goal: to form educated, moral, creative, socially active and capable of self-development personality (Pugacheva et al., 2016). But the methods of achieving the goal of these approaches are different. Extensive approach is realized through the increase in the number of academic disciplines, including increasing the amount of knowledge imparted to students. Intensive approach is based on the formation of the subjective, personally interested student's positions and involves changing of the very structure of the curricula and teaching methods' intensification (Kulyutkin, 1984). We believe that an intensive approach to the development of students' cognitive activity is the most effective. Intensive approach involves the development of pedagogical creativity, identification of types of students' cognitive activity and selection of appropriate methods and techniques of their training activities (Vergasov, 1985). All the above mentioned has led to the goal of the paper - to identify types of students' cognitive activity and to find out the functions of individual educational paths.

\section{Research methodology}

The guiding principle of investigation is the principle of pedagogical creativity, providing a communicative and creative direction of teachers, development of the ability to find new approaches to solving problems. Specificity of pedagogical creativity consists in the fact that the object and at the same time the subject of his professional activity is the student's personality (Bukhvalov, 1993). All other types of creative activity are inferior pedagogical creativity in their complexity and responsibility precisely because of the fact that in the course of pedagogical activity the formation and development of personality occurs. In modern scientific literature pedagogical creativity is understood as a process of solving pedagogical problems in changing circumstances (Kan-Kalik \& Nikandrov, 1990). The creative process of the teacher is seen as an activity aimed at a permanent solution of educational problems' majority in changing circumstances, during which the teacher works out and embodies in the communication the optimum, organic, for this individual, non-standardized educational solutions, which are mediated by the features of the object-subject of pedagogical 
influence (Zagvyazinsky, 1987). Referring to the set of standard and non-standard tasks' solving, the teacher, as well as any researcher builds its activities in accordance with the general heuristic search rules: analysis of pedagogical situations, the projecting of the results in accordance with the original data, the analysis of available resources needed to test the hypothesis and achieve the desired results, evaluation of the data obtained, the formulation of new problems (Yepaneshnikov et al., 2016). In pedagogical science it is recognized that pedagogical work cannot be uncreative because there are unique learners, circumstances, personality of the teacher, and any pedagogical solution must come from these always non-standard factors (Kaloshina, 1983). Development of students' informative activity a priori implies pedagogical creativity, which is reflected in the use of effective methods of solving professional problems, the high quality of its performance, the unity of science and art, in the individualization of pedagogical influence and ability to communicate, respecting the criteria of pedagogical tact. During the research the following methods were used: theoretical (analysis, synthesis, generalization and systematization); sociological (observation, interviews, questionnaires, expert estimation).

\section{Results}

The main results of this study are 1) the types of cognitive activity of students; 2) the functions of individual educational paths; 3) experimental work to verify the effectiveness of individual educational paths.

\section{Types of cognitive activity}

Four types of cognitive activity are revealed: the starting, situational, performing and creative. In the first (starting) type of cognitive activity the student is passive, responds poorly to the demands of the teacher, but is included in the activities under teacher's pressure. The student possesses underdeveloped emotional, intellectual and behavioral abilities and skills for learning in interaction. There is a marked object's position in the educational process. Teacher's tactics in this case is based on the creation the climate of study, which removes the student's sense of fear, stiffness. Most often these students are "neglected" category (mainly by the teacher). "Scrolling" past failures, the students themselves, in advance, reduce the ability of a constructive approach to the new learning task, so it is important to neutralize their negative memories. The main reception, at the same time will be the so-called "emotional strokes" (appeal to the students by name, kind, affectionate tone, and the like). When working with this group of students the teacher should not expect their immediate inclusion in work, since their activity can be increased gradually. One should not offer them training tasks that require a rapid transition from one activity to another. They should be given time to think about the answer, since it is difficult for these students to improvise. One should not shoot down such students during the response by asking unexpected and tricky questions. Strategic direction in the work with these students is their transfer in the learning interaction from the expressed object position into the predominantly subjective position. This is possible thanks to the special atmosphere of classes focused on the psychological emancipation and emotional inclusion of students in a common activity. In this case, a chain is formed: the state of comfort, transparency, removal of fear of joint work, a willingness to engage in cooperation with the teacher or students (Astakhova, 2000).

Typical indicators of the second type of cognitive activity (situational) - is a manifestation of interest and activity only in certain situations (interesting content of educational material, unusual teaching methods). Most likely this is due to emotional excitability, often unsupported skills and abilities to work independently. During the 
lessons such students are easily connected to new types of work, but with difficulties and can easily lose interest in learning. Students belonging to this type of cognitive activity may surprise teacher with quick and correct answers, but this happens only occasionally. Tactics of educational interaction with these students is the constant reinforcement of their subjective (active) state in educational activity. The help of the teacher is valuable, who can help them remove the intellectual fatigue, if necessary, to overcome a strong-willed apathy, to stimulate their interest in learning. We have identified several examples of activation exercises. For example - "delayed guessing". At the beginning of the lecture the teacher offers students a riddle (a surprising fact), the guessing of which will be found during the presentation of educational material. Another example of activation of the learning - "survey-crossword": students fill a crossword puzzle on the theme of the study, which was prepared in advance by the teacher or his assistants. "Aerobatics" can be called a situation where part of the concepts of the crossword "prepares" a new theme. It is found that the students of this type of cognitive activity are inherent in haste and incompleteness of actions, so it is important for them to have the ability to use a response plan based on the reference signals and create algorithms of a training action, tables. But there is one feature: for such students it is easier to remember and use the schemes, which they create themselves (or with a teacher). Thus, the teacher's strategy of actions in dealing with situational-active students is to not only help them to engage in learning activities, but also to support the emotional and intellectual atmosphere throughout the session. Then the student experiences a sense of satisfaction and inspiration not only in the perception of the learning task, but in the course of its implementation. Having experienced the feeling of success once he wants to repeat and consolidate achievements and to show certain intellectual and volitional efforts. If subsequent lessons do not deceive his expectations, then preconditions for the gradual transition to an executive and an active type of knowledge will occur (Kulyutkin, 1984).

Students of the third type of cognitive activity (performing), as a rule, are favorites of teachers. They are readily included in those forms of work which offers teacher. The main advantage of these students is the stability and permanence. However, they have their own problems. For the assiduity and diligence they are often called "learners by rote". But some teachers think that these students study very easily. This is the truth, but for some reason they forget that such apparent easiness - the result of earlier efforts: the ability to focus on the task, carefully to get acquainted with the conditions of the task, strengthen the existing knowledge, to choose the most successful version of the solution. Therefore, these students need in careful attention of the teacher. Sometimes they get bored if the material under study is quite simple. Gradually this type of students is accustomed to limit them by the learning task and do not want or wean to look for unconventional solutions. They understand that the approval of the teacher can be obtained not for something "over and above the original", but simply for the quality work that does not require search for additional material. The main methods for stimulating of the students of this type can be called all problematic, partially search and heuristic situations that are created on the lecture. For example, a "problematic dialogue" when discussing the topic proposed by the teacher, students predict its development. Or "brainstorming", consisting of the following steps: creation of a bank of ideas, analysis of ideas, presentation of the work of the group and the further selection of ideas proposed by experts. Often presenting the ideas, new proposals are born, which are immediately included in the discussion. One can offer students special role situations: students can take the role of "expert" and evaluate the oral and written responses of other students (Lozovaya \& Trotsko, 1989). 
Creative - the fourth type is characterized by bright cognitive activity of a subject position of students. These students have a non-standard way of thinking, vivid imagery perception, especially individual imagination, a unique attitude to the world. However, they often create problems in the educational activity, which is based on the sequence, logic and thoroughness. For example, the teacher proposes to solve any problem, and then adds: "Tell us how to get the answer." He waits step by step explanation of mental actions. But this type of students cannot always explain how the knowledge occurs. Their explanations often go beyond all logic. The activity of the teacher in this type of cognitive activity is to develop the students' need for creativity, desire for self-expression, self-actualization. To help in achieving this goal can techniques that activate the creativity of students, develop imagination, creative thinking and intuition: didactic games, project method (Petrova et al., 2016).

Functions of individual educational paths. Individual educational path - is a personal way of development of students' creative potential, their personal and professional skills needed in modern conditions of life and professional activity (Kliminskaya, 2014). 1.1. It is found that the individual educational paths fulfill the following functions:

1) target - based, which enable the student independently or jointly with the teacher to set a goal of education, determine the steps to achieve it, the pace of progress, adequate forms, methods, means (Turkina, 2006). This feature allows you to find a teaching material, organize such forms of cooperation that will contribute to the student's own initiative, the manifestation and the formation of personality. In practice, the implementation of this function is shown in the preparation of a special training curriculum (for a semester, a year, the entire period of study). The components of such a program are: the goals, objectives, stages, forms and methods of training, personal content of education (compulsory subjects, elective courses, self-study), control system and evaluation of the results (Terentyeva, Pugacheva \& Lunev, 2015).

2) Content- based, contributing to the formation of knowledge, abilities, skills, values, understanding of the world and oneself in this world (Uvarova \& Maksimchenko, 2012). This feature helps students to adapt to the current social and economic situation and establishes creation of varieties educational environment, providing students with the range of opportunities and help in the selection. In practice, the implementation of this function is shown in the organization of the natural or artificially created socio-cultural environment of students, including various kinds of tools and educational content that can provide them with productive activities (Lunev \& Pugacheva, 2013).

3) Competence-based, providing accumulation of educational, social, professional experience (Andreev, 2005). This function ensures the formation of students' readiness to self-actualization, career building. In practice, the implementation of this function is associated with the choice of forms, methods and means of education, organization of control system for the acquisition of knowledge and competencies formation. All work performed by students are issued in the form of reports and gathered in personal achievements folder (portfolio), which in addition contains the characteristics, the results of examinations and tests. Portfolio displays the amount of work performed, the level of formation of competences, diligence and self-esteem of students (Pugacheva, Lunev \& Stukolova, 2014). 


\section{Experimental verification of the effectiveness of individual educational paths}

In the experimental study took part 200 teachers, 350 students of Kazan State Architectural University, who took part in the identification of criteria performance of individual educational paths. Experimental verification was carried out from 2013 to 2016 in three stages: the ascertaining, forming and controlling. At the ascertaining stage the stages of implementation of individual educational paths were identified. 1) Diagnostic. The preparatory stage for a successful learning environment's creation. The leading role is given to the teacher who helps students navigate in the educational material and to select the optimal form for work with the students and they acquire basic knowledge, abilities and skills. 2) goal-setting. It assumes the active cooperation of the student and teacher. The student creates an individual path in the form of a graph indicating the desired level of disciplines' mastering after completing the course, but not below the level inherent in the state educational standards. Together with the teacher results are projected, time frame is determined, algorithm of independent work and forms of interaction with a mentor are selected. 3) motivating. This is a stage of active student activities, when he works with a teacher, attending classes, reports on the work done for a certain period of time work. Depending on the results, the teacher corrects the educational trajectory. At the same time, as a motivational tool such methods as the preparation of a report or presentation can be used, presentation at the conference, participation in multidisciplinary projects, participation in the competition, exemption from routine tests or consultations, offset slice across multiple disciplines can be used. 4) познавательный. Informative. A stage of coherent self-realization of individual educational path by performing individual tasks using a variety of resources. Interaction with the teacher takes the form of group sessions of interactive nature (role-playing, case studies, projects, simulation of professional communicative situations). 5) controlling (evaluation). Monitoring and evaluation of tasks and the degree of individual educational path's implementation is carried out as by the teacher and so by the student that promotes the development of self-control and adequate perception of personal achievement. During the analysis of this work the typical errors are revealed, the causes of failures and successes are analyzed. At the forming stage individual educational paths of 350 students were tested.

At the control stage the performance criteria of individual educational paths were identified: 1) knowledge-based - assimilation of subject knowledge, general cultural and professional competences; 2) the activity-based - possession of skills a) analytical (the ability to analyze their cognitive activity and the results of cognitive activity carried out on its basis), b) projective (skill of goal setting and decision making to perform problems of self-development, find ways and means to solve them), c) organizational ( ability to organize active and independent cognitive activity), g), communicative (the ability to interact with teachers and fellow students in the process of teaching and learning activities); 3) motivational - cognitive interest, learning needs (focus on the mastery of new knowledge, learning the ways of self-knowledge acquisition); 4) reflexive (self-esteem, self-control and self-correction in the exercise of cognitive activity; awareness of the situation and the setting (reformulation) of tasks, moving from the stereotypical type of action, inadequate to the situation, to the development and finding new ways).

\section{Discussions}

Analysis of the literature shows that the problems of informative activity of students and the formation of individual educational paths are the subject of many 
studies. However, none of these studies are interrelated problems. All authors consider them separately, isolated from each other. The problem of the development of cognitive activity is one of the priorities in pedagogy. Informative activity of students is seen, firstly, as a condition of formation of need in knowledge, mastery of skills of intellectual activity, independence, providing the depth and strength of knowledge (Astakhova, 2000; Popkov \& Korzhuev, 2007; Manesheva, 2010). Second, cognitive activity is seen as a dynamic process of didactic interaction of the student with the objects of cognition aimed at mastering the experience of social culture and the expansion of personal value system (Vergasov, 1985; Egorshin \& Pryanichkov, 2002; Davydova, 2005; Stroganova, 2011). Individual educational path of students is understood as an individual style of educational activity, the sequence of educational steps, corresponding to the level of the student, his or her abilities, interests, realized and coordinated by a teacher (Surtaeva, 1998; Labunskaya, 2002; Kemerova, 2010, Goncharova \& Chumicheva 2012; Zaitsev, 2013; Zeer \& Symanyuk 2014, Gert, 2014). We believe that cognitive activity is a kind of educational activity, which assumes a certain level of independence of students in all of its structural components from the problem statement to monitoring, self-monitoring and correction, with the transition from the implementation of the simplest kinds of work to more complex and wearing searching nature. The significance of individual educational path is that the use of this learning format provides development of skills, values that create the motivation for the development of cognitive activity. Construction of individual educational path is a multi-faceted process that can ensure the development of learner's autonomy and initiative, the ability to the fullest realization of his personal and educational potential in the educational process. The student formulates the goals of the forthcoming activities, setting priorities in the organization of activities and carries out self-assessment of personal growth.

\section{Conclusion and Recommendations}

It is found that the decisive role in the knowledge economy belongs to knowledge and the production of knowledge is a source of growth. Currently, investments in knowledge are growing faster than investment in fixed assets. This updates the society's need for the cognitive development of students' activity. Four major types of cognitive activity of students are revealed: the starting, situational, performing and creative. Identified types of cognitive activity, allow us to say that the division of students into the gifted and "the other" is impossible. Each student has a right to express themselves in the process of cognitive activity. The realization of this right is conditioned by the type of student cognitive activity. Types of cognitive activity cause the selection of adequate methods for their learning activities to strengthen students' subject position and to move to the individualization of educational paths. It is found that the efficiency of the development of students' cognitive activity increases, in case of providing the construction of individual educational paths. The functions of individual educational paths are found (target-based, content-based, competence-based), which contribute to the development of creative potential of students, their personal and professional skills needed in the modern conditions of life and professional activities.

The study results allow outlining of prospects for further research of the problem that are associated with the development of training and methodological support of construction of individual educational paths. Paper Submissions can be useful for university professors; staff of continuous professional training and retraining centers for the selection and structuring of the content for continuous professional training of the teaching staff in the universities. 


\section{Disclosure statement}

No potential conflict of interest was reported by the authors.

\section{Notes on contributors}

Vladimir V. Yepaneshnikov - PhD, Associate Professor of the Department of Theory and Methods of Professional Training, Kazan (Volga region) Federal University, Kazan, Russia.

Vladimir I. Kurdyumov - Doctor of Technical Sciences, Professor, Head of the Department "Agricultural Technology, Machinery and Safety", Ulyanovsk State Agricultural Academy named after P. A. Stolypin, Ulyanovsk, Russia.

Larisa E. Zotova - PhD, Associate Professor of the Department of Social Psychology, Moscow State Regional University, Moscow, Russia.

Marina U. Kraeva - PhD, Associate Professor of the Department of Social Psychology, Moscow State Regional University, Moscow, Russia.

Natalya I. Besedkina - PhD, Associate Professor of the Department of Legal Regulation of Economic Activity, Financial University under the Government of the Russian Federation, Moscow, Russia.

Olesya G. Filipenkova - Deputy Head of the Department of State and Legal Disciplines, Plekhanov Russian University of Economics, Moscow, Russia.

\section{References}

Akhmetov, L.G., Khramova, N.A., Sychenkova, A.V., Chudnovskiy, A.D., Pugacheva, N.B., Pavlushin, A.A., Varlamova, M.V. \& Khilsher, V.A. (2016). Selective Support for the Development of Regional Vocational Education Services: the Russian Experience. International Review of Management and Marketing, 6(2), 127-134.

Andreev, A.L. (2005). Competence paradigm in education: experience of the philosophical and methodological analysis. Pedagogy, 4, 19-27.

Astakhova, E. (2000). Informative activity of students: the search for forms of optimization. Alma Mater, 11, 29-32.

Bukhvalov, V.A. (1993). Algorithms for pedagogical creativity. Moscow: Education.

Davydova, L.N. (2005). Different approaches to the defining of the quality of education. Quality. Innovation. Education, 2(14), 5-8.

Egorshin, A.P. \& Pryanichkov S.B. (2002). Methodology for assessing the quality and efficiency of education. School technology, 5, 68-87.

Gert, V.A. (2014). Individuality and individualization of man. Teacher education in Russia, 4, 209-214.

Goncharova, E.V. \& Chumicheva, R.M. (2012). Organization of individual educational trajectory of bachelors' training. Bulletin of the Nizhnevartovsk State Humanitarian University, 2. Direct access: http://cyberleninka.ru/article/n/organizatsiya-individualnoy-obrazovatelnoy-traektorii-obucheniyabakalavrov

Kaloshina, I.P. (1983). The structure and mechanisms of creative activity. Moscow: Publishing House of Moscow State University.

Kan-Kalik, V.A. \& Nikandrov, N.D. (1990). Pedagogical creativity. Moscow: Pedagogy.

Kemerova, N.S. (2010). Projecting of individual trajectory of learning a foreign language in a technical college. Bulletin of Tomsk State Pedagogical University, 2, 53-57.

Knowledge-based society. Budapest. 08-10.11.2003. (2003) Direct access: http://www.sciforum.hu/previous-fora/2003/permanent-update/knowledge-based-society.html

Kulyutkin, Y.N. (1984). Personal factors of cognitive activity of students in the learning process. Questions of Psychology, 5, 41-43.

Labunskaya, N.A. (2002). Individual student educational route: approaches to disclosure. Proceedings of Russian State Pedagogical University named after A.I. Gertsen, 2, 79-90.

Lozovaya, V.I. \& Trotsko, A.V. (1989). Cognitive activity as a pedagogical problem. Soviet pedagogy, 11, 25-31. 
Lunev, A.N., Pugachova, N.B. \& Stukolova, L.Z. (2014). Socially oriented regional economic space as an instrument in managing the development of service sector. Actual Problems of Economics, 155(5), 247250.

Lunev, A.N. \& Pugacheva, N.B. (2013). Social practice as the philosophical basis of pedagogical strategizing in a technical College. Society: Philosophy, History, Culture, 4, 11-16.

Manesheva, R.A. (2010). Individual principles of active learning in the organization of the monitoring of students' knowledge. Bulletin of the Tomsk State Pedagogical University, Pedagogy of the Higher School, 2(92), 40-42.

Osmolovskaya, I.M. (2006). Didactics: a textbook for university students. Moscow: Publishing Center "Academy".

Petrova, T.N., Kirillova, O.V., Sokolova, S.G., Pugacheva, N.B., Galimullina, A.F., Maksimova, O.G., Antonova, T.V. \& Kozhanov, V.V. (2016). Education as the Management of Research Universities Students' Socialization. International Review of Management and Marketing, 6(2), 28-33.

Popkov, V.A. \& Korzhuev, A.V. (2007). The methodology of pedagogy. Moscow: Publishing House of Moscow State University.

Pugacheva, N.B., Lunev, A.N. \& Stukolova, L.Z. (2014). Perspective directions of researches of professional education as a public good and meaningful domain of personality. Modern Problems of Science and Education, 1, 91-94.

Pugacheva, N.B., Ezhov, S.G., Kozhanov, I.V., Kozhanova, M.B., Ogorodnikova, S.V., Oshaev, A.G., Timonin, A.I. \& Goloshumova, G.S. (2016). The model of self-realization readiness formation of research universities students in the process of civic education. International Review of Management and Marketing, 6(1), 128-133.

Stroganova, A.N. (2011). Model of individually-focused training of students in high school. Man and Education, $3,75-78$.

Surtaeva, N.N. (1998). The technology of individual educational trajectory. Chemistry at school, 7, 13-17.

Kliminskaya, S.L. (2014). Individual educational trajectory as a way to improve the effectiveness of teaching foreign languages. Internet journal "Naukovedenie", 4(23). Direct access: http://cyberleninka.ru/article/n/individualnaya-obrazovatelnaya-traektoriya-kak-sposobpovysheniya-effektivnosti-obucheniya-inostrannym-yazykam (reference date: 22/11/2016 ).

Terentyeva, I.V., Pugacheva, N.B. \& Lunev, A.N. (2015). Theoretical methods the experimental work in vocational education pedagogy. Modern Problems of Science and Education, 1-2, 133-138.

Turkina, A.V. (2006). Investigation of students' readiness to the choice of individual educational route. Man and Education, 6, 68-71.

Uvarova, N.M. \& Maksimchenko, T.V. (2012). Individual educational trajectory as a prerequisite for personalprofessional development of college students. Research in Education, 2, 19-24.

Vergasov, V.M. (1985). Activation of cognitive activity of students in higher education. Kiev: Vishcha school

Yepaneshnikov, V.V., Pugacheva, N.B., Goloshumova, G.S., Kuznetsova, V.V., Dobrovolskaya, L.V., Moiseeva, L.V., Garaganov, A.V. \& Litvinenko, N.A. (2016). Pedagogical Management of Civil Education of Research Universities Students. International Review of Management and Marketing, 6(2), 23-27.

Zagvyazinsky, V.I. (1987). Pedagogical creative work of the teacher. Moscow: Pedagogy.

Zaitsev, A.B. (2013). Individually-psychological factors of success of advanced students' training. Bulletin of South Ural State University. Series: Psychology, 2, 65-71

Zeer, E.F \& Symanyuk, E.E. (2014). Individual educational trajectories in continuing education system. Teacher education in Russia, 3, 74-82. 